To appear in Volume 3, Issue 4 (December 2017)

SpringerLink Header: Insomnia and Pharmacotherapy (H Attarian and M Kay-Stacey, Section Editors)

Topical Collection on Insomnia and Pharmacotherapy

\title{
Orexin receptor antagonists
}

\author{
Daniel Hoyer ${ }^{1,2,3}$ and Laura H. Jacobson ${ }^{1,2}$
}

${ }^{1}$ Department of Pharmacology \& Therapeutics, School of Biomedical Sciences, Faculty of Medicine, Dentistry and Health Sciences, The University of Melbourne, Parkville, Victoria 3010, Australia, ${ }^{2}$ The Florey Institute of Neuroscience and Mental Health, University of Melbourne, Parkville, 3010, Australia, ${ }^{3}$ Department of Molecular Medicine, The Scripps Research Institute, 10550 N. Torrey Pines Road, La Jolla, CA 92037, USA

Correspondence:

Prof. Daniel Hoyer, PhD, DSc, FBPhS, Chair and Head, Department of Pharmacology and Therapeutics, School of Biomedical Sciences, Faculty of Medicine, Dentistry and Health Sciences, The University of Melbourne, Parkville, Victoria 3010, Australia.

d.hoyer@unimelb.edu.au

Dr. Laura H. Jacobson, The Florey Institute of Neuroscience and Mental Health, University of Melbourne, Parkville, 3010, Australia. laura.jacobson@florey.edu.au

Keywords: Orexin, hypocretin, orexin receptors, antagonists, hypothalamus, sleep, feeding, reward, addiction, insomnia, narcolepsy/cataplexy.

\section{Abstract:}

Purpose of review: This paper focuses on the role of orexin receptors in sleep as evidenced in recent preclinical and clinical work. Orexin $A$ and $B$ and their two receptors $\left(O X_{1} R\right.$ and $\left.O X_{2} R\right)$ play essential roles in arousal and sleep/ wake regulation, addiction and stress. The absence of orexin producing cells in the lateral hypothalamus or of orexins in the CSF results in narcolepsy with cataplexy in humans. This finding and others on sleep phenotypes in orexin or OXR KO rodents, have triggered drug discovery programmes on OXR antagonists for the treatment of insomnia and other disorders. Recent findings: Several OXR antagonists, most of which are dual $O X_{1} R / O X_{2} R$ antagonists (DORAs), have now reached Phase II / III clinical trials. Suvorexant $\left(\right.$ Belsomra $\left.{ }^{\circledR}\right)$, recently registered in Japan, United States and Australia for insomnia, is the first orexinergic hypnotic principle of this new class. DORAs promote sleep primarily by increasing REM sleep, with little effect on slow wave sleep (SWS). Based on rodent studies, it is clear that the $\mathrm{OX}_{2} \mathrm{R}$ is the primary target mediating sleep promotion by DORAs and other OXR antagonists. We briefly review preclinical and clinical data of OXR antagonists in situations of unperturbed and perturbed sleep, e.g. insomnia and various neurological diseases. Summary: We propose that REM sleep enhancement by DORAs may provide opportunities to treat specific neurological disorders. By contrast, $\mathrm{OX}_{2} \mathrm{R}$ antagonists such as seltorexant (JNJ-54717793 / MIN-202) or MK-1064, may have broader applications as 
they appear to promote balanced sleep in preclinical models and should, in theory, have a lower narcoleptic/cataplectic potential. These concepts require further validation as more OXR antagonists move beyond early stages of clinical development.

\section{Introduction:}

The first clinical data on an orexin receptor antagonist developed for the treatment of insomnia were presented in 2007 [1], just 9 years after the initial publications describing the two orexin peptides and their two receptors $\left(O X_{1} R\right.$ and $\left.O X_{2} R\right)[2,3]$. This short time frame between discovery and clinical data is unheard of, at least in the field of low molecular weight compounds, where a normal development program can take up to 15 years from preclinical research to regulatory submission and more than 30 years from initial drug target discovery to market entry. The first orexin receptor antagonist in the clinical setting was almorexant [1], developed by the Swiss Biotech Actelion; initially alone, then in collaboration with Glaxo Smith Kline (GSK). Almorexant reached phase III clinical studies and was eventually stopped for undisclosed reasons, most likely a safety issue [4]. Orexin (OX), a neuropeptide that comes in 2 forms (OXA and OXB), was discovered independently by two groups. One team was at Scripps in La Jolla, led by G. Sutcliffe. They reported the discovery of 2 peptides in January 1998, which they named hypocretins (HCRT1 and HCRT2), since their structure was reminiscent of incretins $[2,3]$ and because the 3000-7000 cells in rodent brain producing hypocretins are exclusively located in the lateral hypothalamus (LH). One month later, in February 1998, a group led by M. Yanagisawa (Howard Hughes Medical Institutes / Dallas), reported the deorphanisation of two G-protein-coupled receptors (GPCRs): these were named $O X_{1} R$ and $O X_{2} R$ and their endogenous ligands named Orexin $A$ and $B$ [3]. The name orexin, from the Greek "orexis" for appetite, related to the observation that orexin applied intracerebroventricularly, increased food intake [5-7]. Orexins are also produced exclusively by LH cells, and their sequence is identical to that of HCRT1 and HCRT2, respectively; being, as they were, the same peptides as hypocretins.

Ultimately, it was decided that the genes would be named hypocretin and the gene products i.e., peptides and receptors, named orexin [8, 9]. There are approximately 70,000 cells producing orexin in the human brain, all located in the LH [10], whereas $\mathrm{OX}_{1} \mathrm{R}$ and $\mathrm{OX}_{2} \mathrm{R}$ have a wide brain distribution $[11,12]$. One year later, orexin peptide knock out mice were reported to have rapid transitions between wake and REM sleep [13]; such transitions do not occur normally, except in patients suffering from narcolepsy with cataplexy. Indeed, post mortem brain analysis showed that such patients lack orexin-producing LH cells [10, 14-16], possibly as the result of an autoimmune disorder [17, 18]. Thus, CSF orexin levels are extremely low or below detection limit in patients suffering from narcolepsy with cataplexy $[14,19-21]$. On the other hand, orexin levels are relatively normal in a number of neurological or psychiatric diseases, e.g. depression, narcolepsy without cataplexy, whereas in Alzheimer's disease, CSF orexin levels tend to be elevated $[22,23]$. The $\mathrm{OX}_{2} \mathrm{R}$ is nonfunctional in dogs suffering from narcolepsy with cataplexy $[24,25]$, but there is no evidence for an OXR defect in human patients. Furthermore, LH orexin-expressing cells do actively fire during wake periods, with a peak preceding sleep onset; then, firing attenuates almost completely during sleep, to start again in the next wake state; there is a reduced firing rate during quiet wake in comparison to active wake [26]. 
Collectively, these findings supported that the orexin system is strongly involved in sleep wake regulation and arousal [27-32]. By 2005, it was agreed by an expert committee that narcolepsy with cataplexy is due to the absence of orexin $A$ in the brain and that the very low CSF levels of the peptide can be used as a biomarker of the disorder [33-35]. Orexin KO mice show behaviours reminiscent of narcolepsy with cataplexy, which is triggered by strong positive (e.g. food, sex) or negative emotional triggers (fear), as is the case in human patients $[13,36]$. Orexin peptide KO mice show reduced locomotion, reduced food intake, but increased body mass [36, 37]. Orexin receptor KO mice have different sleep phenotypes [3841]: $\mathrm{OX}_{1} \mathrm{R}$ KO show almost no sleep disturbances, whereas $\mathrm{OX}_{2} \mathrm{R}$ KO have a moderate phenotype with increased sleep phases and the appearance of, albeit rare, fast transitions from wake to REM. By contrast, double $O X_{1} R / O X_{2} R$ KO mice, like orexin KO mice, show frequent cataplexy attacks, a greater number of rapid transitions from wake to REM sleep and highly fragmented sleep throughout the light and dark phases. The narcolepsy phenotype of such mice can be corrected by orexin gene transfer $[42,43]$ or by applying orexin intra-nasally: this approach was also tried in humans suffering from narcolepsy with cataplexy, but with limited success given the pharmacokinetic liabilities of the orexin peptide [44]. Based on the sleep and feeding phenotypes in various murine models, Biotech and Pharma companies started drug development program s soon after the discovery of orexin, which were initially aimed at food intake and obesity, with e.g. OX ${ }_{1} R$ antagonists [45]. However, the results observed in animal models did not translate into a clinical setting and this approach has apparently been abandoned. Concomitantly, dual OXR antagonists were investigated in sleep, e.g. at Actelion, Glaxo and Merck. Thus, candidate drugs such as almorexant, SB-649868, suvorexant and filorexant, all dual OXR antagonists, reached phase II / III clinical development within the last few years [1, 46-48] (and see [49-52]). Suvorexant is the first OXR antagonist registered for the treatment of insomnia in Japan, the United States, and Australia, with other applications pending [53-55]. We shall describe these efforts below. Further research is also actively ongoing in the addiction field, since orexin and OXR play a role in drug addiction, e.g. alcohol, cocaine and others, with either $\mathrm{OX}_{1} \mathrm{R}$ and/or $\mathrm{OX}_{2} \mathrm{R}$ as the main targets [56-59] (see also [60]).

\section{The role orexin and orexin receptors in sleep / wake regulation:}

At Novartis, given that $O X_{1} R K O$ mice have almost no sleep phenotype and $O X_{1} R / O X_{2} R K O$ replicate the narcolepsy/ cataplexy phenotype observed in orexin $K O$ and in humans, we initially investigated the respective contributions of $\mathrm{OX}_{1} R$ and $O X_{2} R$ in sleep regulation. We tested almorexant in mice lacking either the peptide or the receptors, namely $O X_{1} R, O X_{2} R$ and both $O X_{1} R / O X_{2} R$ [61]. Almorexant dose-dependently induced sleep in wild type (WT) and $\mathrm{OX}_{1} \mathrm{R}$ KO mice, whereas it was devoid of effects in $\mathrm{OX}_{2} \mathrm{R}$ KO or double OXR KO mice. Thus, the data indicated that the $\mathrm{OX}_{1} \mathrm{R}$ receptor did not contribute to almorexant-induced sleep, that the sleep effects were entirely $\mathrm{OX}_{2} \mathrm{R}$-dependent, and furthermore, that no other receptors were responsible for the effects of almorexant. Interestingly, almorexant had a clear effect on total sleep time in WT mice, whereby REM was increased more than NREM sleep [61]. A closer look at the $\mathrm{OX}_{1} \mathrm{R} \mathrm{KO}$ mice suggested that almorexant disproportionately increased REM sleep in this mutant, albeit without increasing total sleep time (TST). Interestingly, C. Dugovic and colleagues at Janssen reported that a combination of $O X_{1} R$ and $O X_{2} R$ antagonists $[62,63]$ produces more marked effects on REM sleep than $\mathrm{OX}_{2} \mathrm{R}$ blockade alone. Indeed, this team 
commonly uses REM sleep as a marker for $\mathrm{OX}_{1} \mathrm{R}$ receptor engagement [64] (see also [65]). Different roles for $O X_{1} R$ and $O X_{2} R$ in REM and NREM sleep have thus been advocated [66-68].

The logical consequence of these findings is that a selective $\mathrm{OX}_{2} \mathrm{R}$ antagonist would probably induce sleep to the same extent as dual antagonists, but with a reduced potential for incurring cataplectic attacks, an issue raised early on by M. Tafti [69]. This hypothesis was rejected by most teams working on dual OXR antagonists, as no spontaneous attacks have been documented in animals (rodents, dogs, non-human primates) treated with any of the current OXR antagonists. However, as we shall describe below, Suvorexant is contraindicated in patients suffering from narcolepsy with cataplexy, as it produces cataplectic attacks in narcoleptic dogs [54]. Similarly, almorexant induces cataplexy in sensitive mice [70]. In any case, we and others took the route to develop $\mathrm{OX}_{2} \mathrm{R}$ selective antagonists (see $[49,71-73])$. One of the main arguments for that path is that dual antagonists induce REM/NREM imbalance and sleep onset REM (SOREM), whereas $\mathrm{OX}_{2} \mathrm{R}$ antagonists produce a more physiologically balanced sleep. Whether a high level of REM sleep is detrimental, can be discussed at length [74, 75], however we felt convinced that SOREM, which can be seen with dual antagonists, is not desirable in any patient population (see also [76, 77]). In contrast, enhancing REM sleep may ultimately prove beneficial in patients where there is a REM sleep insufficiency or disruptions such as fragmentation, as seen in a number of neurological or psychiatric diseases, including post-traumatic stress disorder (PTSD) and Alzheimer's disease (see [78, 79]).

\section{Clinical status of dual orexin receptor antagonists:}

\section{Almorexant:}

Almorexant, ACT 078573, is a dual receptor antagonist with high affinity and almost equal nanomolar potency at $\mathrm{OX}_{1} \mathrm{R}$ and $\mathrm{OX}{ }_{2} \mathrm{R}$ [1]. Almorexant was the first dual antagonist to be tested in insomnia patients [80]. Almorexant dose-dependently induced sleep in various species, increasing both NREM and REM sleep, in contrast to zolpidem, which reduced REM sleep profoundly; both drugs had similar effects on total sleep time (TST) [1]. Almorexant, unlike other hypnotics, does not show drug-drug interactions with alcohol and a number of other drugs and importantly, does not affect memory, in contrast to $G_{A B A}$ receptor modulators [81-84]. Another interesting feature of the antagonist is that animals treated with almorexant are easily woken up and return to sleep readily, whereas under zolpidem, waking is more difficult $[1,85]$ (see also $[86,87]$ ). These points indicate that orexin receptor antagonism is not subject to the same limitations as benzodiazepines and Z drugs (memory impairment, alcohol and other drug-drug interactions). Furthermore, almorexant shows no evidence of withdrawal effects or drug-dependency potential after treatment cessation. To the contrary, orexin receptor antagonists may be good candidates for various forms of addiction [60].

Almorexant has been investigated in clinical studies for efficacy, pharmacokinetics (PK) and pharmacodynamics (PD), formulation, abuse potential and drug-drug interactions. There are seven published studies evaluating almorexant's potential as a hypnotic; 4 in healthy subjects, including one in elderly [1,88-90] and 3 in insomnia patients, one of which was also in elderly subjects $[80,91,92]$. In single ascending dose studies, almorexant was tested at 1 , 
$5,25,50,100,200,400$ and $1000 \mathrm{mg}$ in healthy male subjects: effects on wake and sleep became prominent at $200 \mathrm{mg}$, with a marked decrease in latency to stage 2 (S2) sleep [1, 88]. A 2012 multiple ascending dose study revealed significant effects in polysomnography (PSG) outcomes, with almorexant reducing latency to REM and increasing REM sleep duration [89]. Two Phase III clinical studies have only recently been published. In 709 insomnia patients, almorexant (100 and $200 \mathrm{mg}$ ) was compared to zolpidem (10 mg) and placebo over 16 days. Wake after sleep onset (WASO), latency to persistent sleep (LPS) were reduced and TST increased by $200 \mathrm{mg}$ almorexant [92]. PSG showed increases particularly in S2 and REM sleep on day 1-2 of treatment versus baseline, although only REM sleep was increased as a \% of TST. Latency to stage 1 (S1), S2 and REM sleep were all reduced on days 1-2, but not SWS, with latency to REM sleep more affected than other stages (-15 and -18 min by 100 and 200 mg doses, respectively). The effect on latency to REM sleep was similar after 15-16 days of dosing, while the effects on other sleep stages were lost [92].

Almorexant was also tested in a Phase III study in elderly patients with primary insomnia [91] at 25, 50, 100 and $200 \mathrm{mg}$ in groups of up to 100 patients each. Almorexant dosedependently increased sleep, with a marked effect on wake after sleep onset (WASO; up to $46.5 \mathrm{~min} / \mathrm{night}$ ) and a small reduction in LPS. There was a clear increase in S2 (up to 20 $\mathrm{min} /$ night) and especially REM sleep, (up to $25 \mathrm{~min} / \mathrm{night}$ ), but no increase in slow wave sleep (SWS). Latency to stage 1 or SWS was hardly affected, whereas latency to REM was reduced by up to 30 minutes. Thus almorexant (like other dual antagonists), increases sleep by affecting S2 and REM, but not slow wave sleep (see figure 1). As stated in Roth et al., 2017: "Similar to previous data with the dual orexin antagonist SB-649868, almorexant consistently increased the amount of total time spent in REM and reduced latency to REM." [91]. The incidence of side effects in the elderly subjects study was comparable to the placebo group, although somnolence and fatigue are mentioned. Special attention was paid to muscle weakness and cataplexy, which were not observed in the study, an important consideration in the elderly, given the higher propensity for falls in this population. Almorexant was stopped after phase III (see [4] and [89]).

\section{SB-649868}

SB-649868 is also a dual OXR antagonist [48], which binds with high affinity and shows almost equal nanomolar potency at $\mathrm{OX}_{1} \mathrm{R}$ and $\mathrm{OX} \mathrm{X}_{2} \mathrm{R}$ in calcium mobilization assays. SB-649868 was discovered at Smith Kline Beecham (SKB) and with the successive mergers, ended up in the Glaxo development pipeline, since the discovery of orexin receptors by Yanagisawa's team was supported by the SKB orphan receptor program [3]. SB-649868 has been tested in various clinical settings: in healthy volunteers subjected to sleep deprivation (10-80 mg); in situational insomnia (10 and $30 \mathrm{mg}$, compared to zolpidem 10mg), and eventually in patients with "primary" insomnia (10, 30 and $30 \mathrm{mg}$ ) [93-95]. All studies were performed in male subjects. In healthy volunteers, SB-649868 dosed at 30 and $60 \mathrm{mg}$ produced sleep, but had no effect on stage 1 or SWS; SB-649868 affected only REM sleep. It had clear effects on WASO and LPS, again primarily by reducing latency to REM, with 1 and 7 subjects showing sleep-onset REM sleep (SOREM) at 30 and $60 \mathrm{mg}$ respectively (see table 1). As stated by the authors: "A dose-dependent increase in absolute and percent REM sleep and reduction in REM sleep latency was observed mainly at the 60-mg dose" [95]. Sleep architecture when analyzed 
as percentage of TST revealed that NREM, S1 and SWS were significantly reduced, whereas the REM proportion was dose-dependently increased. Although a dual antagonist, our kinetic studies suggest that dissociation from $\mathrm{OX}_{1} \mathrm{R}$ is slower than from $\mathrm{OX}_{2} \mathrm{R}$ [96], suggesting some $O X_{1} R$ selectivity at equilibrium, which may explain the pronounced effects on REM and REM sleep duration and latency.

The PK of SB-649868 has been determined in healthy volunteers at 5, 15 and 30mg: Tmax was at 1-3 hours or more with a lipid-rich meal, and T1/2 ranged from 4 to 7 hours. Therefore, in clinical studies, the compound was administered 90 minutes before bedtime. When given for 15 days, Cmax and AUC of SB-649868 increased, indicating accumulation. Side effects were moderate, with evidence of next morning somnolence, fatigue and dizziness in a dose dependent manner. Seven subjects out of 19 at $30 \mathrm{mg}$ showed SOREM (REM latency < 15 minutes) in the phase I study. The compound had no negative effects in a series of cognitive tasks performed the next morning, except for the word recall test. Hallucinations, sleep paralysis and cataplexy were not noted [95]. SB-649868 appeared to be stopped after phase II for undisclosed reasons (although there were no announcements to that effect).

\section{Suvorexant:}

Suvorexant from Merck, also known as MK-4305 or Belsomra ${ }^{\circledR}[47,97,98]$ is the most widely tested sleep drug in the world [53, 99-109] (reviewed in [51]). Suvorexant is a dual OXR antagonist, with high affinity and almost equal nanomolar potency at $O X_{1} R$ and $O X_{2} R$. The compound has been tested in a number of species: rats, mice, dogs, and non-human primates. Across all, there is good evidence for sleep inducing effects, although with little effect on SWS. Suvorexant induced sleep in a purely $\mathrm{OX}_{2} \mathrm{R}$ receptor-dependent manner, in that no sleep enhancing effects are seen in $\mathrm{OX}_{2} \mathrm{R}$ KO mice, and like all dual OXR antagonist, suvorexant drives essentially REM sleep, e.g.: "...increases in TST for suvorexant compared with placebo were mainly attributable to greater time spent in REM sleep and, to a lesser degree, stage-2 sleep" [103]. There were no negative effects on cognition or synergism with alcohol (although monkey data submitted to FDA suggest a slight interaction) or withdrawal or dependence. Normal animals showed no muscle weakness or cataplectic attacks [110113]. This may not be surprising, since cataplexy tends to occur in situations of strong positive or negative stimuli [69]; thus, narcoleptic dogs may show an enhanced propensity for cataplectic attacks when suvorexant is given in combination with a food presentation challenge (see [53]). Thus, the FDA recommended suvorexant not to be prescribed to narcolepsy with cataplexy patients. Suvorexant was subjected to extensive phase II trials in "primary insomnia" patients at 10, 20, 40 and $80 \mathrm{mg}$. During phase III, Suvorexant was tested at 15, 20, 30 and $40 \mathrm{mg}$ in adult and elderly insomnia patients, during 3 months and then up to 12 months, with a large number of patients - up to 600 patients per arm. Suvorexant dosedependently increased sleep, reduced WASO and LPS, with no evidence for withdrawal symptoms, cognitive impairment or reduced efficacy after one year of administration, in the longest investigator-driven study of a hypnotic to date. Similar to almorexant, suvorexant affected REM sleep and to a lesser degree stage 2 sleep with no effect on SWS [103]. Suvorexant, especially in the high doses, reduced latency to REM and produced SOREM in a dose-dependent manner in some patients. Suvorexant has been submitted for registration in 
Japan, US and Australia. Japan accepted the submission, whereas the US FDA rejected the first application in 2012/13, recommending to skip the high doses, and to start dosing at 10 mg (or even $5 \mathrm{mg}$ depending on CYP interactions and obesity), with 15 and $20 \mathrm{mg}$ as the highest doses, given once per night. Suvorexant was then approved by the FDA (Food \& Drug Administration) in 2014. Australia rejected the first application, but a revised submission was successful in late 2016. Interestingly the Australian TGA (Therapeutic Goods Administration) accepted the higher doses, in contrast to the FDA, as the Australian agency was not convinced of the efficacy of the $10 \mathrm{mg}$ dose.

The PK of suvorexant is rather slow, with a Tmax between 2-3 hours and a terminal half-life of 12-19 hours, with longer half-life noted especially in women and obese patients [53]. Plasma suvorexant levels reach steady state after 4-5 days of repeated dosing, although it is only administered at bed time. In addition, suvorexant like almorexant, SB-649868 and filorexant, dissociates very slowly from orexin receptors once bound [61, 96]. Thus, traditional PK may underestimate target engagement, as suvorexant may occupy receptors longer than expected from the PK data.

Suvorexant is generally considered to be well-tolerated; the main side effect was dosedependent next morning somnolence, which explains why the FDA rejected the 30 and 40 $\mathrm{mg}$ doses, as this was also seen to affect the driving ability of patients. Although suvorexant was in general as good as the comparators, there were still patients who showed a worsening of driving skills, as highlighted by the assessment of Dr Farkas of the FDA (see [54, 114]). Indeed the FDA's response to suvorexant is in line with their recent unilateral decision to reduce the dosage of a number of sleeping pills, including Z-drugs $[115,116]$. Other side effects of suvorexant are strange dreams and hallucinations, and there may be some muscle weakness in certain subjects. Altogether, based on these finding, the FDA recommended 10 $\mathrm{mg}$ as a starting dose (or $5 \mathrm{mg}$ for obese patients) with the possibility to increase to 15 and maximally $20 \mathrm{mg} / \mathrm{night}$. Suvorexant prescribing information recommends the compound to be taken when already in bed (to avoid potential falls), only once per night and with at least 7 hours of sleeping time available before wake time. It is also recommended not to drive the next morning, and as stated above, suvorexant is contra-indicated in patients suffering from narcolepsy with cataplexy.

\section{Filorexant:}

Filorexant, or MK6096 [46, 98] was Merck's backup candidate to Suvorexant; it went into phase II clinical studies. In contrast to Suvorexant, filorexant has a relatively short T $1 / 2$ of 3-6 hours [117]. The compound has been tested in various species [98] and in essence, filorexant replicates the effects of suvorexant, both in preclinical models and in the clinic $[46,117,118]$. In a phase II trial [117], filorexant was tested at 2.5, 5, 10 and $20 \mathrm{mg}$ in primary insomnia adult male and female patients vs placebo for 4 weeks. Filorexant at 10 and $20 \mathrm{mg}$ clearly increased LPS, WASO and sleep efficiency. As with other dual OXR antagonists, TST, REM latency and duration and S2 sleep represented the primary effects as measured by PSG; SWS was hardly affected by filorexant, even after 4 weeks' treatment. Somnolence was dosedependently increased, but there were no major other side effects, nor was there any adverse signs following treatment cessation, i.e. no rebound insomnia [117]. Filorexant is currently not listed in the Merck development portfolio. 


\section{Lemborexant:}

Lemborexant, or E2006, from Esai is a dual OXR antagonist with nanomolar affinity at both receptors [119]. Functionally, lemborexant is about 10 fold selective for $\mathrm{OX}_{2} \mathrm{R}$ over $\mathrm{OX}_{1} \mathrm{R}(0.44$ vs $5.7 \mathrm{nM}$ in calcium mobilisation assays, respectively). In preclinical studies, it produces sleep with effects on both NREM and REM sleep, although there appears to be a dosedependent increase at REM sleep at the doses tested (10 and $30 \mathrm{mg} / \mathrm{kg}$ ), whereas NREM was already at ceiling responses [119]. Lemborexant is in phase II/III for the treatment of insomnia (ClinicalTrials.com ID: NCT01995838, NCT02952820, NCT03001557), with an abstract published on one study which investigated 1, 2.5, 5, 10, 15, $25 \mathrm{mg}$ or placebo administered for 15 nights [120]. PSG was conducted at baseline and on treatment days 1/2 and 14/15. Lemborexant induced sleep, reduced WASO during the second half of the night, although a detailed clinical study remains to be published. Lemborexant was apparently welltolerated, with moderate adverse events, e.g. headache and dose-related somnolence.

\section{ACT-462206}

ACT-462206 is the second dual OXR antagonist from Actelion [121, 122]: it has been tested in healthy male volunteers at doses between 5 and $1500 \mathrm{mg}$. The compound had rather slow PK features in humans, with dose-dependent half-lives from 5.3 to 12.4 hours and a Tmax of 1.5 to 4 hours. In contrast, in rodents the compound shows a rapid absorption and elimination, with a $T 1 / 2$ of less than 2 hours, suggesting interesting PK features. The pharmacodynamic effects investigated in the clinical setting were vigilance and attention, alertness, and motor coordination, which lasted less than expected from the PK, whereas effects on sleep by PSG are not documented. At the highest tested doses, significant plasma concentrations of ACT462206 were still present 48 - 72 hours after administration, clearly too long to avoid the next morning somnolence that has been a concern to FDA with a number of sleep-inducing pills over the recent past $[115,116]$. ACT-462206 has apparently been discontinued after the phase I trials.

\section{Selective orexin receptor antagonists:}

\section{Seltorexant:}

JNJ-42847922, also known as JNJ-922, MIN-202 or Seltorexant, is a high-affinity antagonist with about 100 fold selectivity for $\mathrm{OX}_{2} \mathrm{R}[72,73]$. The compound is in co-development by Janssen / Johnson \& Johnson and Minerva Neurosciences; it is promoted as producing balanced sleep in insomnia and depression. In rats, Seltorexant (3-30 mg/kg) dosedependently reduced latency to NREM and prolonged NREM sleep, whereas it affected REM sleep minimally. Seltorexant's effects on sleep were maintained upon 7-day repeated dosing (30 mg/kg). Like other OXR antagonists, it had no effect in $\mathrm{OX}_{2} \mathrm{R}$ knockout mice [64]. In a single ascending dose study in healthy subjects, Seltorexant $(10,20,40$ and $80 \mathrm{mg})$ increased somnolence and displayed a favourable PK and safety profile [64]. The majority of subsequent clinical information about Seltorexant is available only as press releases and a meeting abstract. A Phase II trial was performed in 20 insomnia patients with major depressive disorder (MDD) stably treated with selective serotonin reuptake inhibitors (SSRIs) 
and serotonin / noradrenalin reuptake inhibitors (SNRIs) [123, 124]. The patients received placebo and Seltorexant at 10, 20 or $40 \mathrm{mg}$ in a cross-over design. Sleep onset was rapid and TST was increased up to $45 \mathrm{~min}$, with a dose-dependent reduction in LPS as measured by PSG. Sleep was described as physiological or restorative [125]. In insomnia patients without psychiatric comorbidity, Seltorexant was tested vs placebo over 7 days at $2 \times 20 \mathrm{mg}$ : the PSG data showed positive effects on LPS, TST and WASO ([126] and NCT02464046). Side effects were somnolence and abnormal dreams, the compound is otherwise reported as safe [127]. The compound (2x20 mg) was also tested against placebo and zolpidem (10 mg) in healthy volunteers on cognitive performance and simulated driving. The full reports are pending.

\section{MK-1064:}

MK-1064 [128, 129] is a selective $\mathrm{OX}_{2} \mathrm{R}$ antagonist (as are MK-3697 [130], and MK-8133 [131]). MK-1064 was in a phase I study in healthy volunteers [129], but the compound is not listed in the Merck development pipeline. MK-1064 at 50, 120 and $250 \mathrm{mg}$ decreased LPS and WASO, and increased TST and sleep efficiency. Both NREM and REM sleep were increased moderately. The human PK data shows that at these doses, significant plasma levels of MK1064 are observed after $16-24$ hours. Overall, the team concluded that MK-1064 had no advantage over DORAs for either main or side effects, which were all moderate [129]. MK1064 has not been tested in insomnia patients.

\section{JNJ-54717793:}

JNJ-54717793 is a potent, brain penetrant, 50-fold selective $\mathrm{OX}_{1} \mathrm{R}$ antagonist [64]. As expected, JNJ-54717793 has minimal effect on sleep in rats or WT mice. Interestingly, and along the lines elaborated above with regard to the summation of $\mathrm{OX}_{1} \mathrm{R}$ and $\mathrm{OX}_{2} \mathrm{R}$ antagonism enhancing REM sleep, JNJ-54717793 selectively promotes REM sleep in $\mathrm{OX}_{2} \mathrm{R}$ knockout mice and reduces REM latency, without changing NREM sleep [61-63, 65], although $\mathrm{OX}_{1} \mathrm{R}$ antagonism in isolation has no sedative or hypnotic effects. JNJ-54717793 when tested in two rodent panic models, attenuated $\mathrm{CO}_{2}$ and sodium lactate-induced panic-like behaviours and cardiovascular responses. The compound was devoid of effects on baseline locomotor or autonomic activity or sleep. Its current development status is unclear, but the preclinical data are highly interesting.

\section{Conclusions:}

There is no doubt that OXR antagonists produce sleep in patients with insomnia. This is true for both dual antagonists (suvorexant, almorexant, filorexant, SB-649868 and lemborexant) as well as the $\mathrm{OX}_{2} \mathrm{R}$ antagonist seltorexant. Rodent PSG studies with OXR antagonists have proven highly translational across species in this regard, accurately predicting the effects of the drugs in humans, including patients with insomnia. Of note, suvorexant and most dual OXR antagonists have been tested in patients with "primary insomnia" as defined by DSM IV, although primary and secondary insomnia are not distinguished in DSM V [132]. Interestingly, seltorexant is apparently also efficacious in insomniacs who suffer from MDD (see [123-125]), although peer-reviewed reports are not yet available. 
Dual OXR antagonists affect primarily REM and S2 sleep, with signs of SOREM with some agents, whereas $\mathrm{OX}_{2} \mathrm{R}$ antagonists seem to induce a more balanced NREM/REM sleep. It is unclear what the consequences of increasing primarily REM sleep are, compared to the enhancement of both REM sleep and SWS; the long-term use of suvorexant and other dual OXR antagonists will clarify this matter. It is, however, obvious that the orexin receptor antagonist approach is different and indeed superior to benzodiazepines and $Z$ drugs with regard to effects on sleep architecture. GABA $A$ receptor modulators reduce REM sleep, which is important for the consolidation of certain types of memory [133]. Indeed, a hypnotic that increases REM sleep may be of specific advantage in treating disorders where REM is reduced or disrupted. Addressing the orexin system may also be safer than the GABA $A_{A}$ system with regard to side-effects and drug-drug interactions. Benzodiazepines and Zdrugs show profound interactions with alcohol, and lead to a general inhibition of the brain activity, like anesthetics; in addition, it is difficult to reverse the hypnotic state produced by these agents. OXR antagonists, in contrast, block the arousal, wake-promoting and motivated behavioral effects of orexin. They do not generally dampen the brain function, and thus allow treated subjects to awaken rapidly in case of need, and to fall back to sleep as long as the active agent remains on board.

Currently, suvorexant is the only approved orexin receptor antagonist and only in US, Japan and Australia. More dual OXR antagonists are in development, as well as selective $\mathrm{OX}_{2} \mathrm{R}$ antagonists (e.g. Seltorexant). There are also a number of additional clinical trials under way with suvorexant and other OXR antagonists in patients with various psychiatric and neurodegenerative disorders, including Alzheimer's disease, where an orexin receptor antagonist may have beneficial effects, not only due to its direct effects on sleep, but also indirectly via the reduction of beta amyloid levels in the brain [134-136] (see ClinicalTrials.com study IDs NCT02750306 and NCT03077620). A study on Parkinson's disease is also reported to be recruiting patients, which may determine whether or not any residual, subclinical sleep paralysis induced by OXR antagonists may be capitalised upon for the treatment of REM sleep behaviour disorder which occurs in this disorder (ClinicalTrials.com ID: NCT02729714). The potential of OXR antagonists in various addictions has not been addressed here, but is certainly promising $[60,137]$. The many clinical studies underway will determine what potential OXR antagonists may have as a disease modifying agent in these indications. In the meanwhile, the future of orexin receptor antagonists as hypnotics appears to be well assured.

\section{Compliance with Ethics Guidelines}

\section{Conflict of Interest}

Daniel Hoyer and Laura H. Jacobson declare no conflicts of interest.

\section{Human and Animal Rights and Informed Consent}

This article does not contain any studies with human or animal subjects performed by any of the authors.

\section{References:}


*Important reference

**Very Important reference

1. Brisbare-Roch C, Dingemanse J, Koberstein R, Hoever P, Aissaoui H, Flores S, et al. Promotion of sleep by targeting the orexin system in rats, dogs and humans. Nature Medicine. 2007;13 (2):150-5.

2. De Lecea L, Kilduff TS, Peyron C, Gao XB, Foye PE, Danielson PE, et al. The hypocretins: Hypothalamus-specific peptides with neuroexcitatory activity. Proceedings of the National Academy of Sciences of the United States of America. 1998;95 (1):322-7.

3. Sakurai T, Amemiya A, Ishii M, Matsuzaki I, Chemelli RM, Tanaka H, et al. Orexins and orexin receptors: A family of hypothalamic neuropeptides and $\mathrm{G}$ protein-coupled receptors that regulate feeding behavior. Cell. 1998;92 (4):573-85.

4. GlaxoSmithKline/Actelion. Actelion and GSK discontinue clinical development of almorexant. 2011;Accessed on 19 Aug 2017; available at: https://www.gsk.com/en$\mathrm{gb} / \mathrm{media} /$ press-releases/gsk-and-actelion-discontinue-clinical-development-of-almorexant/.

5. Beuckmann CT, Yanagisawa M. Orexins: from neuropeptides to energy homeostasis and sleep/wake regulation. Journal of Molecular Medicine-Jmm. 2002;80 (6):329-42.

6. Sakurai T, Mieda M, Tsujino N. The orexin system: roles in sleep/wake regulation. In: Vaudry $\mathrm{H}$, Shioda S, editors. Phylogenetic Aspects of Neuropeptides: from Invertebrates to Humans2010. p. 149-61.

7. Yamanaka A, Sakurai $T$, Katsumoto $T$, Yanagisawa M, Goto K. Chronic intracerebroventricular administration of orexin-A to rats increases food intake in daytime, but has no effect on body weight. Brain Research. 1999;849 (1-2):248-52.

8. Alexander SP, Benson HE, Faccenda E, Pawson AJ, Sharman JL, Spedding M, et al. The Concise Guide to PHARMACOLOGY 2013/14: G protein-coupled receptors. Br J Pharmacol. 2013;170 (8):1459-581. Epub 2014/02/13.

9. Gotter AL, Webber AL, Coleman PJ, Renger JJ, Winrow CJ. International Union of Basic and Clinical Pharmacology. LXXXVI. Orexin Receptor Function, Nomenclature and Pharmacology. Pharmacological Reviews. 2012;64 (3):389-420.

10. Thannickal TC, Moore RY, Nienhuis R, Ramanathan L, Gulyani S, Aldrich M, et al. Reduced number of hypocretin neurons in human narcolepsy. Neuron. 2000;27 (3):469-74.

11. Kilduff TS, de Lecea L. Mapping of the mRNAs for the hypocretin/orexin and melaninconcentrating hormone receptors: Networks of overlapping peptide systems. Journal of Comparative Neurology. 2001;435 (1):1-5.

12. Marcus JN, Aschkenasi CJ, Lee CE, Chemelli RM, Saper CB, Yanagisawa M, et al. Differential expression of orexin receptors 1 and 2 in the rat brain. Journal of Comparative Neurology. 2001;435 (1):6-25.

13. Chemelli RM, Willie JT, Sinton CM, Elmquist JK, Scammell T, Lee C, et al. Narcolepsy in orexin knockout mice: Molecular genetics of sleep regulation. Cell. 1999;98 (4):437-51.

14. Peyron C, Faraco J, Rogers W, Ripley B, Overeem S, Charnay Y, et al. A mutation in a case of early onset narcolepsy and a generalized absence of hypocretin peptides in human narcoleptic brains. Nature Medicine. 2000;6 (9):991-7.

15. Taheri S, Mignot E. The genetics of sleep disorders. Lancet Neurology. 2002;1 (4):242-

50.

16. Thannickal TC, Nienhuis R, Siegel JM. Localized Loss of Hypocretin (Orexin) Cells in Narcolepsy Without Cataplexy. Sleep. 2009;32 (8):993-8. 
17. Scammell TE. The frustrating and mostly fruitless search for an autoimmune cause of narcolepsy. Sleep. 2006;29 (5):601-2.

18. Tafti M, Lammers GJ, Dauvilliers Y, Overeem S, Mayer G, Nowak J, et al. NarcolepsyAssociated HLA Class I Alleles Implicate Cell-Mediated Cytotoxicity. Sleep. 2016;39 (3):581-7. Epub 2015/11/01.

19. Dauvilliers $Y$, Baumann CR, Carlander B, Bischof M, Blatter T, Lecendreux M, et al. CSF hypocretin-1 levels in narcolepsy, Kleine-Levin syndrome, and other hypersomnias and neurological conditions. J Neurol Neurosurg Psychiatry. 2003;74 (12):1667-73. Epub 2003/11/26.

20. Nishino S, Ripley B, Overeem S, Lammers GJ, Mignot E. Hypocretin (orexin) deficiency in human narcolepsy. Lancet. 2000;355 (9197):39-40.

21. Nishino S, Ripley B, Overeem S, Nevsimalova S, Lammers GJ, Vankova J, et al. Low cerebrospinal fluid hypocretin (orexin) and altered energy homeostasis in human narcolepsy. Annals of Neurology. 2001;50 (3):381-8.

22. Dauvilliers Y, Amulf I, Mignot E. Narcolepsy with cataplexy. Lancet. 2007;369 (9560):499-511.

23. Dauvilliers YA, Lehmann S, Jaussent I, Gabelle A. Hypocretin and brain beta-amyloid peptide interactions in cognitive disorders and narcolepsy. Frontiers in Aging Neuroscience. 2014;6.

24. Lin L, Faraco J, Li R, Kadotani H, Rogers W, Lin XY, et al. The sleep disorder canine narcolepsy is caused by a mutation in the hypocretin (orexin) receptor 2 gene. Cell. 1999;98 (3):365-76.

25. Mishima K, Fujiki N, Yoshida Y, Sakurai T, Honda M, Mignot E, et al. Hypocretin receptor expression in canine and murine narcolepsy models and in hypocretin-ligand deficient human narcolepsy. Sleep. 2008;31 (8):1119-26.

26. Alam MN, Gong H, Alam T, Jaganath R, McGinty D, Szymusiak R. Sleep-waking discharge patterns of neurons recorded in the rat perifornical lateral hypothalamic area. Journal of Physiology-London. 2002;538 (2):619-31.

27. Boutrel B, Cannella N, de Lecea L. The role of hypocretin in driving arousal and goaloriented behaviors. Brain Research. 2010;1314:103-11.

28. Carter ME, Borg JS, de Lecea L. The brain hypocretins and their receptors: mediators of allostatic arousal. Current Opinion in Pharmacology. 2009;9 (1):39-45.

29. Carter ME, Brill J, Bonnavion P, Huguenard JR, Huerta R, de Lecea L. Mechanism for Hypocretin-mediated sleep-to-wake transitions. Proceedings of the National Academy of Sciences of the United States of America. 2012;109 (39):E2635-E44.

30. Carter ME, de Lecea L, Adamantidis A. Functional wiring of hypocretin and LC-NE neurons: implications for arousal. Frontiers in Behavioral Neuroscience. 2013;7.

31. Saper CB, Cano G, Scammell TE. Homeostatic, circadian, and emotional regulation of sleep. Journal of Comparative Neurology. 2005;493 (1):92-8.

32. Saper CB, Chou TC, Scammell TE. The sleep switch: hypothalamic control of sleep and wakefulness. Trends in Neurosciences. 2001;24 (12):726-31.

33. Scammell TE. The neurobiology, diagnosis, and treatment of narcolepsy. Annals of Neurology. 2003;53 (2):154-66.

34. Scammell TE. Narcolepsy. N Engl J Med. 2015;373 (27):2654-62. Epub 2015/12/31.

35. Scammell TE, Willie JT, Guilleminault C, Siegel JM, Int Working Grp Rodent Models N. A Consensus Definition of Cataplexy in Mouse Models of Narcolepsy. Sleep. 2009;32 (1):1116. 
36. Hara J, Nambu T, Beuckmann CT, Goto K, Yanagisawa M, Sakurai T. Genetic ablation of orexin neurons in mice: A mouse model of narcolepsy. Sleep. 2001;24:A156-A.

37. Hara J, Yanagisawa $Y$, Sakurai T. Difference in obesity phenotype between orexinknockout mice and orexin neuron-deficient mice with same genetic background and environmental conditions. Neuroscience Letters. 2005;380 (3):239-42.

38. Kisanuki YY, Chemelli RM, Tokita S, Willie JT, Sinton CM, Yanagisawa M. Behavioral and polysomnographic characterization of orexin-1 receptor and orexin-2 receptor double knockout mice. Sleep. 2001;24:A22-A.

39. Sakurai T. The neural circuit of orexin (hypocretin): maintaining sleep and wakefulness. Nat Rev Neurosci. 2007;8 (3):171-81. Epub 2007/02/15.

40. Willie JT, Chemelli RM, Sinston CM, Tokita H, Williams SC, Kisanuki YY, et al. Distinct narcolepsy syndromes in Orexin receptor-2 and Orexin null mice: Molecular genetic dissection of non-REM and REM sleep regulatory processes. Neuron. 2003;38 (5):715-30.

41. Willie JT, Chemelli RM, Sinton CM, Yanagisawa M. To eat or to sleep? Orexin in the regulation of feeding and wakefulness. Annual Review of Neuroscience. 2001;24:429-58.

42. Liu M, Thankachan S, Kaur S, Begum S, Blanco-Centurion C, Sakurai T, et al. Orexin (hypocretin) gene transfer diminishes narcoleptic sleep behavior in mice. European Journal of Neuroscience. 2008;28 (7):1382-93.

43. Mieda M, Willie JT, Sakurai T. Rescue of narcoleptic orexin neuron-ablated mice by ectopic overexpression of orexin peptides. In: Nishino S, Sakurai T, editors. Orexin/Hypocretin System: Physiology and Pathophysiology. Lydic, R.

Baghdoyan, H.A. ed. New Jersey, USA.: Humana Press Inc.; 2006.

44. Weinhold SL, Seeck-Hirschner M, Nowak A, Hallschmid M, Goder R, Baier PC. The effect of intranasal orexin-A (hypocretin-1) on sleep, wakefulness and attention in narcolepsy with cataplexy. Behavioural Brain Research. 2014;262:8-13.

45. Scammell TE, Winrow CJ. Orexin Receptors: Pharmacology and Therapeutic Opportunities. Annual Review of Pharmacology and Toxicology, Vol 51, 2011. 2011;51:24366.

46. Coleman PJ, Schreier JD, Cox CD, Breslin MJ, Whitman DB, Bogusky MJ, et al. Discovery of (2R,5R)-5-\{ (5-Fluoropyridin-2-yl)oxy methyl\}-2-methylpiperidin-1-yl 5 -methyl-2(pyrimidin-2-yl)phenyl methanone (MK-6096): A Dual Orexin Receptor Antagonist with Potent Sleep-Promoting Properties. Chemmedchem. 2012;7 (3):415-24.

47. Cox CD, Breslin MJ, Whitman DB, Schreier JD, McGaughey GB, Bogusky MJ, et al. Discovery of the Dual Orexin Receptor Antagonist (7R)-4-(5-Chloro-1,3-benzoxazol-2-yl)-7methyl-1,4-diazepan-1-yl 5-met hyl-2-(2H-1,2,3-triazol-2-yl)phenyl methanone (MK-4305) for the Treatment of Insomnia. Journal of Medicinal Chemistry. 2010;53 (14):5320-32.

48. Di Fabio R, Pellacani A, Faedo S, Roth A, Piccoli L, Gerrard P, et al. Discovery process and pharmacological characterization of a novel dual orexin 1 and orexin 2 receptor antagonist useful for treatment of sleep disorders. Bioorganic \&amp; Medicinal Chemistry Letters. 2011;21 (18):5562-7.

49. Hoyer $D$, Jacobson $\mathrm{LH}$. Orexin in sleep, addiction and more: is the perfect insomnia drug at hand? Neuropeptides. 2013;47 (6):477-88. Epub 2013/11/13.

50. Winrow CJ, Renger JJ. Discovery and development of orexin receptor antagonists as therapeutics for insomnia. Br J Pharmacol. 2014;171 (2):283-93. Epub 2013/06/05.

51. Jacobson LH, Callander GE, Hoyer D. Suvorexant for the treatment of insomnia. Expert Rev Clin Pharmacol. 2014;7 (6):711-30. Epub 2014/10/17. 
52. Jacobson LH, Chen S, Mir S, Hoyer D. Orexin OX2 Receptor Antagonists as Sleep Aids. Curr Top Behav Neurosci. 2017;33:105-36. Epub 2016/12/03.

53. FDA. Suvorexant Advisory Committee Briefing Document, NDA 204569. 2013;Accessed 19 Aug 2017; available at: https://www.fda.gov/downloads/AdvisoryCommittees/CommitteesMeetingMaterials/Drugs/ PeripheralandCentralNervousSystemDrugsAdvisoryCommittee/UCM352970.pdf.

- 54. Farkas R. Suvorexant safety and efficacy. US Food and Drug Administration. 2013;Accessed 19 Aug 2017; available at: https://www.fda.gov/downloads/AdvisoryCommittees/CommitteesMeetingMaterials/Drugs/ PeripheralandCentralNervousSystemDrugsAdvisoryCommittee/UCM354215.pdf.

The very comprehensive review of the Suvorexant submission by the FDA.

55. FDA. Highlights of prescribing information: Belsorma ${ }^{\circledR}$ (suvorexant) tabl. 2014;Accessed 19 Aug 2017; available at: http://www.accessdata.fda.gov/drugsatfda docs/label/2014/204569s000lbledt.pdf.

56. Boutrel B, Kenny PJ, Specio SE, Martin-Fardon R, Markou A, Koob GF, et al. Role for hypocretin in mediating stress-induced reinstatement of cocaine-seeking behavior. Proceedings of the National Academy of Sciences of the United States of America. 2005;102 (52):19168-73.

57. Boutrel B, de Lecea L. Addiction and arousal: The hypocretin connection. Physiology \&amp; Behavior. 2008;93 (4-5):947-51.

58. Boutrel B, Steiner N, Halfon O. The hypocretins and the reward function: what have we learned so far? Frontiers in Behavioral Neuroscience. 2013;7.

59. Uslaner JM, Winrow CJ, Gotter AL, Roecker AJ, Coleman PJ, Hutson PH, et al. Selective orexin 2 receptor antagonism blocks cue-induced reinstatement, but not nicotine selfadministration or nicotine-induced reinstatement. Behavioural Brain Research. 2014;269:615.

60. Lawrence AJ, de Lecea L. Behavioral Neuroscience of Orexin/Hypocretin. Geyer MA, Ellenbroek BA, Marsden CA, Barnes TRE, Andersen SL, editors. Cham, Switzerland: Springer International Publishing; 2017.

61. Mang GM, Durst T, Burki H, Imobersteg S, Abramowski D, Schuepbach E, et al. The Dual Orexin Receptor Antagonist Almorexant Induces Sleep and Decreases Orexin-Induced Locomotion by Blocking Orexin 2 Receptors. Sleep. 2012;35 (12):1625-35.

62. Dugovic C, Shelton JE, Yun S, Bonaventure P, Shireman BT, Lovenberg TW. Orexin-1 receptor blockade dysregulates REM sleep in the presence of orexin-2 receptor antagonism. Front Neurosci. 2014;8:28. Epub 2014/03/05.

63. Dugovic C, Shelton JE, Aluisio LE, Fraser IC, Jiang XH, Sutton SW, et al. Blockade of Orexin-1 Receptors Attenuates Orexin-2 Receptor Antagonism-Induced Sleep Promotion in the Rat. Journal of Pharmacology and Experimental Therapeutics. 2009;330 (1):142-51.

64. Bonaventure P, Dugovic C, Shireman B, Preville C, Yun S, Lord B, et al. Evaluation of JNJ-54717793 a Novel Brain Penetrant Selective Orexin 1 Receptor Antagonist in Two Rat Models of Panic Attack Provocation. Front Pharmacol. 2017;8:357. Epub 2017/06/27.

65. Hoyer D, Durst T, Fendt M, Jacobson LH, Betschart C, Hintermann S, et al. Distinct effects of IPSU and suvorexant on mouse sleep architecture. Front Neurosci. 2013;7:235. Epub 2013/12/26.

66. Chen LC, McKenna JT, Bolortuya Y, Winston S, Thakkar MM, Basheer R, et al. Knockdown of orexin type 1 receptor in rat locus coeruleus increases REM sleep during the dark period. European Journal of Neuroscience. 2010;32 (9):1528-36. 
67. Mieda M, Hasegawa E, Kisanuki YY, Sinton CM, Yanagisawa M, Sakurai T. Differential Roles of Orexin Receptor-1 and-2 in the Regulation of Non-REM and REM Sleep. Journal of Neuroscience. 2011;31 (17):6518-26.

68. Hasegawa E, Mieda M, Kisanuki Y, Yanagisawa M, Sakurai T. Differential roles of orexin receptor-1 and-2 in the regulation of non-REM and REM sleep. Neuroscience Research. 2011;71:E169-E.

69. Tafti M. Reply to 'Promotion of sleep by targeting the orexin system in rats, dogs and humans'. Nature Medicine. 2007;13 (5):525-6.

70. Black SW, Morairty SR, Fisher SP, Chen TM, Warrier DR, Kilduff TS. Almorexant Promotes Sleep and Exacerbates Cataplexy in a Murine Model of Narcolepsy. Sleep. 2013;36 (3):325-36.

71. Betschart C, Hintermann S, Behnke D, Cotesta S, Fendt M, Gee CE, et al. Identification of a novel series of orexin receptor antagonists with a distinct effect on sleep architecture for the treatment of insomnia. J Med Chem. 2013;56 (19):7590-607. Epub 2013/08/24.

72. Letavic MA, Bonaventure P, Carruthers NI, Dugovic C, Koudriakova T, Lord B, et al. Novel Octahydropyrrolo[3,4-c]pyrroles Are Selective Orexin-2 Antagonists: SAR Leading to a Clinical Candidate. J Med Chem. 2015;58 (14):5620-36. Epub 2015/06/19.

73. Bonaventure P, Shelton J, Yun S, Nepomuceno D, Sutton S, Aluisio L, et al. Characterization of JNJ-42847922, a Selective Orexin-2 Receptor Antagonist, as a Clinical Candidate for the Treatment of Insomnia. J Pharmacol Exp Ther. 2015;354 (3):471-82. Epub 2015/07/17.

74. Riemann D, Spiegelhalder K, Nissen C, Hirscher V, Baglioni C, Feige B. REM Sleep Instability - A New Pathway for Insomnia? Pharmacopsychiatry. 2012;45 (5):167-76.

75. Riemann D. Nonrestorative Sleep: A New Perspective. Sleep. 2013;36 (5):633-4.

76. Staner L, Van Veeren C, Stefos G, Hubain PP, Linkowski P, Mendlewicz J. Neuroendocrine and clinical characteristics of major depressed patients exhibiting sleeponset REM. Biological Psychiatry. 1998;43 (11):817-21.

77. Stefos G, Staner L, Kerkhofs M, Hubain P, Mendlewicz J, Linkowski P. Shortened REM latency as a psychobiological marker for psychotic depression? An age-, gender-, and polarity-controlled study. Biological Psychiatry. 1998;44 (12):1314-20.

78. Mander BA, Winer JR, Jagust WJ, Walker MP. Sleep: A Novel Mechanistic Pathway, Biomarker, and Treatment Target in the Pathology of Alzheimer's Disease? Trends Neurosci. 2016;39 (8):552-66. Epub 2016/06/22.

79. Spoormaker $\mathrm{VI}$, Montgomery P. Disturbed sleep in post-traumatic stress disorder: secondary symptom or core feature? Sleep Med Rev. 2008;12 (3):169-84. Epub 2008/04/22.

80. Hoever P, Dorffner G, Benes H, Penzel T, Danker-Hopfe H, Barbanoj MJ, et al. Orexin Receptor Antagonism, a New Sleep-Enabling Paradigm: A Proof-of-Concept Clinical Trial. Clinical Pharmacology \&amp; Therapeutics. 2012;91 (6):975-85.

81. Dietrich $\mathrm{H}$, Jenck $\mathrm{F}$. Intact learning and memory in rats following treatment with the dual orexin receptor antagonist almorexant. Psychopharmacology. 2010;212 (2):145-54.

82. Steiner MA, Lecourt H, Strasser DS, Brisbare-Roch C, Jenck F. Differential Effects of the Dual Orexin Receptor Antagonist Almorexant and the GABA(A)-alpha 1 Receptor Modulator Zolpidem, Alone or Combined with Ethanol, on Motor Performance in the Rat. Neuropsychopharmacology. 2011;36 (4):848-56.

83. Steiner MA, Lecourt $\mathrm{H}$, Jenck $\mathrm{F}$. The dual orexin receptor antagonist almorexant, alone and in combination with morphine, cocaine and amphetamine, on conditioned place 
preference and locomotor sensitization in the rat. International Journal of Neuropsychopharmacology. 2013;16 (2):417-32.

84. Hoch M, Hay JL, Hoever P, de Kam ML, te Beek ET, van Gerven JMA, et al. Dual orexin receptor antagonism by almorexant does not potentiate impairing effects of alcohol in humans. European Neuropsychopharmacology. 2013;23 (2):107-17.

85. Parks GS, Warrier DR, Dittrich L, Schwartz MD, Palmerston JB, Neylan TC, et al. The Dual Hypocretin Receptor Antagonist Almorexant is Permissive for Activation of WakePromoting Systems. Neuropsychopharmacology. 2016;41 (4):1144-55. Epub 2015/08/21.

-86. Tannenbaum PL, Tye SJ, Stevens J, Gotter AL, Fox SV, Savitz AT, et al. Inhibition of Orexin Signaling Promotes Sleep Yet Preserves Salient Arousability in Monkeys. Sleep. 2016;39 (3):603-12. Epub 2016/03/05.

This and the following paper show that In contrast to benzodiazepines, $Z$ drugs and other hypnotics, orexin antagonists allow treated animals to be easily aroused from drug-induced sleep.

87. Tannenbaum PL, Stevens J, Binns J, Savitz AT, Garson SL, Fox SV, et al. Orexin receptor antagonist-induced sleep does not impair the ability to wake in response to emotionally salient acoustic stimuli in dogs. Front Behav Neurosci. 2014;8:182. Epub 2014/06/07.

88. Hoever P, de Haas S, Winkler J, Schoemaker RC, Chiossi E, van Gerven J, et al. Orexin Receptor Antagonism, a New Sleep-Promoting Paradigm: An Ascending Single-Dose Study With Almorexant. Clinical Pharmacology \&amp; Therapeutics. 2010;87 (5):593-600.

89. Hoever P, de Haas S, Dorffner G, Chiossi E, van Gerven J, Dingemanse J. Orexin receptor antagonism: an ascending multiple-dose study with almorexant. Journal of Psychopharmacology. 2012;26 (8):1071-80.

90. Hoever P, Hay J, Rad M, Cavallaro M, van Gerven JM, Dingemanse J. Tolerability, Pharmacokinetics, and Pharmacodynamics of Single-Dose Almorexant, an Orexin Receptor Antagonist, in Healthy Elderly Subjects. Journal of Clinical Psychopharmacology. 2013;33 (3):363-70.

-91. Roth T, Black J, Cluydts R, Charef P, Cavallaro M, Kramer F, et al. Dual Orexin Receptor Antagonist, Almorexant, in Elderly Patients With Primary Insomnia: A Randomized, Controlled Study. Sleep. 2017;40 (2). Epub 2017/04/02.

This and the following publication, are the few papers that describe comprehensively the effects of almorexant on sleep using PSG in insomniac patients.

92. Black J, Pillar G, Hedner J, Polo O, Berkani O, Mangialaio S, et al. Efficacy and safety of almorexant in adult chronic insomnia: a randomized placebo-controlled trial with an active reference. Sleep Med. 2017;36:86-94. Epub 2017/07/25.

93. Bettica P, Nucci G, Pyke C, Squassante L, Zamuner S, Ratti E, et al. Phase I studies on the safety, tolerability, pharmacokinetics and pharmacodynamics of SB-649868, a novel dual orexin receptor antagonist. Journal of Psychopharmacology. 2012;26 (8):1058-70.

94. Bettica P, Squassante L, Groeger JA, Gennery B, Winsky-Sommerer R, Dijk DJ. Differential Effects of a Dual Orexin Receptor Antagonist (SB-649868) and Zolpidem on Sleep Initiation and Consolidation, SWS, REM Sleep, and EEG Power Spectra in a Model of Situational Insomnia. Neuropsychopharmacology. 2012;37 (5):1224-33.

-•95. Bettica P, Squassante L, Zamuner S, Nucci G, Danker-Hopfe H, Ratti E. The Orexin Antagonist SB-649868 Promotes and Maintains Sleep in Men with Primary Insomnia. Sleep. 2012;35 (8):1097-104.

A full description of the effects of SB-649868 on sleep in insomniac patients using PSG. 
96. Callander GE, Olorunda M, Monna D, Schuepbach E, Langenegger D, Betschart C, et al. Kinetic properties of "dual" orexin receptor antagonists at OX1R and OX2R orexin receptors. Front Neurosci. 2013;7:230. Epub 2014/01/01.

97. Winrow CJ, Coleman PJ, Cox CD, Doran SM, Breslin MJ, Schreier JD, et al. SLEEP PROMOTING EFFECTS OF MK-4305-A NOVEL DUAL OREXIN RECEPTOR ANTAGONIST. Sleep. 2010;33:A4-A.

98. Winrow CJ, Gotter AL, Cox CD, Tannenbaum PL, Garson SL, Doran SM, et al. Pharmacological characterization of MK-6096-A dual orexin receptor antagonist for insomnia. Neuropharmacology. 2012;62 (2):978-87.

99. Connor K, Budd K, Snavely D, Liu K, Hutzel-Mann J, Benca R, et al. Efficacy and safety of suvorexant, an orexin receptor antagonist, in patients with primary insomnia: a 3-month phase 3 trial (trial \#1). Journal of Sleep Research. 2012;21:97-.

100. Herring WJ, Connor KM, Snyder E, Snavely DB, Zhang Y, Hutzelmann J, et al. Suvorexant in Patients with Insomnia: Pooled Analyses of Three-Month Data from Phase-3 Randomized Controlled Clinical Trials. J Clin Sleep Med. 2016;12 (9):1215-25. Epub 2016/07/12.

101. Herring WJ, Connor KM, Snyder E, Snavely DB, Zhang Y, Hutzelmann J, et al. Clinical profile of suvorexant for the treatment of insomnia over 3 months in women and men: subgroup analysis of pooled phase-3 data. Psychopharmacology (Berl). 2017;234 (11):170311. Epub 2017/03/08.

102. Herring WJ, Ma JS, Snyder E, Svetnik V, Hutzelmann J, Liu K, et al. Power Spectral Profile of the Orexin Receptor Antagonist Suvorexant (MK-4305) in Primary Insomnia Patients and Healthy-Subjects. Biological Psychiatry. 2012;71 (8):297S-8S.

103. Herring WJ, Snyder E, Budd K, Hutzelmann J, Snavely D, Liu K, et al. Orexin receptor antagonism for treatment of insomnia A randomized clinical trial of suvorexant. Neurology. 2012;79 (23):2265-74.

104. Herring WJ, Snyder E, Paradis E, Hutzelmann J, Liu MC, Snavely D, et al. Suvorexant, an orexin receptor antagonist, in preventing symptom return in patients with insomnia after 1 year of treatment: a randomised, double-blind, placebo-controlled study. Journal of Sleep Research. 2012;21:351-.

105. Sun H, Yee KL, Gill S, Liu W, Li X, Panebianco D, et al. Psychomotor effects, pharmacokinetics and safety of the orexin receptor antagonist suvorexant administered in combination with alcohol in healthy subjects. J Psychopharmacol. 2015;29 (11):1159-69. Epub 2015/10/16.

106. Sun $H$, Kennedy WP, Wilbraham D, Lewis $N$, Calder $N$, Li XD, et al. Effects of Suvorexant, an Orexin Receptor Antagonist, on Sleep Parameters as Measured by Polysomnography in Healthy Men. Sleep. 2013;36 (2):259-67.

107. Ma J, Svetnik V, Snyder E, Lines C, Roth T, Herring WJ. Electroencephalographic power spectral density profile of the orexin receptor antagonist suvorexant in patients with primary insomnia and healthy subjects. Sleep. 2014;37 (10):1609-19. Epub 2014/09/10.

- 108. Michelson D, Snyder E, Paradis E, Chengan-Liu M, Snavely DB, Hutzelmann J, et al. Safety and efficacy of suvorexant during 1-year treatment of insomnia with subsequent abrupt treatment discontinuation: a phase 3 randomised, double-blind, placebo-controlled trial. Lancet Neurol. 2014;13 (5):461-71. Epub 2014/04/01.

The effects of suvorexant on sleep druing a 1 year phase 3 trial, one of the longest and most comprehensive ever performed with any hypnotic agent in insomniac patients. 
109. Snyder E, Ma J, Svetnik V, Connor KM, Lines C, Michelson D, et al. Effects of suvorexant on sleep architecture and power spectral profile in patients with insomnia: analysis of pooled phase 3 data. Sleep Med. 2016;19:93-100. Epub 2016/05/21.

-110. Uslaner JM, Tye SJ, Eddins DM, Wang XH, Fox SV, Savitz AT, et al. Orexin Receptor Antagonists Differ from Standard Sleep Drugs by Promoting Sleep at Doses That Do Not Disrupt Cognition. Science Translational Medicine. 2013;5 (179).

Orexin receptor antagonists do not affect cognition and overall performance in contrast to other hypnotics as described in this and the following 3 papers.

111. Fox SV, Gotter AL, Tye SJ, Garson SL, Savitz AT, Uslaner JM, et al. Quantitative electroencephalography within sleep/wake states differentiates GABAA modulators eszopiclone and zolpidem from dual orexin receptor antagonists in rats. Neuropsychopharmacology. 2013;38 (12):2401-8. Epub 2013/06/01.

112. Ramirez AD, Gotter AL, Fox SV, Tannenbaum PL, Yao L, Tye SJ, et al. Dual orexin receptor antagonists show distinct effects on locomotor performance, ethanol interaction and sleep architecture relative to gamma-aminobutyric acid-A receptor modulators. Front Neurosci. 2013;7:254. Epub 2014/01/09.

113. Gotter AL, Garson SL, Stevens J, Munden RL, Fox SV, Tannenbaum PL, et al. Differential sleep-promoting effects of dual orexin receptor antagonists and GABAA receptor modulators. BMC Neurosci. 2014;15:109. Epub 2014/09/23.

114. Vermeeren A, Vets E, Vuurman EF, Van Oers AC, Jongen S, Laethem T, et al. On-theroad driving performance the morning after bedtime use of suvorexant 15 and $30 \mathrm{mg}$ in healthy elderly. Psychopharmacology (Berl). 2016;233 (18):3341-51. Epub 2016/07/18.

115. FDA. Questions and Answers: Risk of next-morning impairment after use of insomnia drugs; FDA requires lower recommended doses for certain drugs containing zolpidem (Ambien, Ambien CR, Edluar, and Zolpimist). 10 Jan 2013. 2013;Accessed on 19 Aug 2017; available at: https://www.fda.gov/Drugs/DrugSafety/ucm334041.htm.

116. FDA. Drug Safety Communication: FDA approves new label changes and dosing for zolpidem products and a recommendation to avoid driving the day after using Ambien CR. 10 Jan 2013. 2013;Accessed on 19 Aug 2017; available at: https://www.fda.gov/Drugs/DrugSafety/ucm352085.htm.

117. Connor KM, Mahoney E, Jackson S, Hutzelmann J, Zhao X, Jia N, et al. A Phase II DoseRanging Study Evaluating the Efficacy and Safety of the Orexin Receptor Antagonist Filorexant (MK-6096) in Patients with Primary Insomnia. Int J Neuropsychopharmacol. 2016;19 (8). Epub 2016/03/17.

118. Sun H, Brown K, Calder N, Li X, Yee K, Perlstein I, et al. A Dual Orexin Receptor Antagonist, Enhances Sleep Onset and Maintenance as Measured by PSG in Healthy Male Subjects. In: Okawa M, Shimizu T, editors. Worldsleep2011; Kyoto: Sleep and Biological Rhythms; 2011. p. PO-1-240.

119. Yoshida Y, Naoe Y, Terauchi T, Ozaki F, Doko T, Takemura A, et al. Discovery of (1R,2S)-2-\{[(2,4-Dimethylpyrimidin-5-yl)oxy]methyl\}-2-(3-fluorophenyl)-N-(5-fluor opyridin-2yl)cyclopropanecarboxamide (E2006): A Potent and Efficacious Oral Orexin Receptor Antagonist. J Med Chem. 2015;58 (11):4648-64. Epub 2015/05/09.

120. Pinner K, Hong Q, Murphy P, Moline M, Dhadda S, Yardley J, et al. Lemborexant Effects on Sleep Maintenance in the Second Half of the Night. Journal of the American Geriatrics Society. 2017;65 (Supplement S1):S47 (A88).

121. Boss C, Roch-Brisbare C, Steiner MA, Treiber A, Dietrich H, Jenck F, et al. Structureactivity relationship, biological, and pharmacological characterization of the proline 
sulfonamide ACT-462206: a potent, brain-penetrant dual orexin 1/orexin 2 receptor antagonist. ChemMedChem. 2014;9 (11):2486-96. Epub 2014/08/26.

122. Hoch M, van Gorsel H, van Gerven J, Dingemanse J. Entry-into-humans study with ACT-462206, a novel dual orexin receptor antagonist, comparing its pharmacodynamics with almorexant. J Clin Pharmacol. 2014;54 (9):979-86. Epub 2014/04/03.

123. Brooks S, Kent J, Jacobs G, Van Amerongen G, Kezic I, Luthringer R, et al. The orexin-2 antagonist JNJ-42847922 (MIN-202) improves sleep in patients with major depressive disorder (MDD) suffering from comorbid insomnia. European Neuropsychopharmacology. 2016;26 (Supplement 2):S408-S9 (P.2.b.050).

124. Minerva Neurosciences. Press Release 21 Jan 2015: Minerva Neuroscience Reports Positive Phase 1 Data with MIN-202, Selective Orexin-2 Antagonist for Treatment of Sleep Disorders Including Primary and Comorbid Insomnia. 2015; http://ir.minervaneurosciences.com/releases.cfm ?ReleaselD=892355.

125. Minerva Neurosciences. Press release 16 June 2015: Minerva Neurosciences Provides Update on MIN-202, Selective Orexin-2 Receptor Antagonist. 2015.

126. EU Clinical Trials Register. A Randomized, Placebo-controlled, 2-way Crossover, Double-blind Study to Evaluate the Efficacy, Safety and Tolerability of JNJ-42847922 in Subjects With Insomnia Disorder Without Psychiatric Comorbidity. . 2017;Accessed 30 Aug 2017; available at: https://www.clinicaltrialsregister.eu/ctr-search/trial/2015-00167222/results.

127. Minerva Neurosciences. Press Release 11 Jan 2016: Minerva Neurosciences Announces Favorable Top Line Results From MIN-202 Phase 2A Clinical Trial in Insomnia Disorder. 2016; http://ir.minervaneurosciences.com/releasedetail.cfm?ReleaselD=949714.

128. Roecker AJ, Mercer SP, Schreier JD, Cox CD, Fraley ME, Steen JT, et al. Discovery of 5"chloro-N-[(5,6-dimethoxypyridin-2-yl)methyl]-2,2':5',3"-terpyridine-3'-carbo xamide (MK1064): a selective orexin 2 receptor antagonist (2-SORA) for the treatment of insomnia. ChemMedChem. 2014;9 (2):311-22. Epub 2014/01/01.

129. Gotter AL, Forman MS, Harrell CM, Stevens J, Svetnik V, Yee KL, et al. Orexin 2 Receptor Antagonism is Sufficient to Promote NREM and REM Sleep from Mouse to Man. Sci Rep. 2016;6:27147. Epub 2016/06/04.

130. Roecker AJ, Reger TS, Mattern MC, Mercer SP, Bergman JM, Schreier JD, et al. Discovery of MK-3697: a selective orexin 2 receptor antagonist (2-SORA) for the treatment of insomnia. Bioorg Med Chem Lett. 2014;24 (20):4884-90. Epub 2014/09/25.

131. Kuduk SD, Skudlarek JW, DiMarco CN, Bruno JG, Pausch MH, O'Brien JA, et al. Identification of MK-8133: An orexin-2 selective receptor antagonist with favorable development properties. Bioorg Med Chem Lett. 2015;25 (12):2488-92. Epub 2015/05/20.

132. American Psychiatric Association. Diagnostic and statistical manual of mental disorders. 5 ed. Arlington, VA: American Psychiatric Publishing; 2013.

133. Dudai Y, Karni A, Born J. The Consolidation and Transformation of Memory. Neuron. 2015;88 (1):20-32. Epub 2015/10/09.

134. Kang JE, Lim MM, Bateman RJ, Lee JJ, Smyth LP, Cirrito JR, et al. Amyloid-beta dynamics are regulated by orexin and the sleep-wake cycle. Science. 2009;326 (5955):10057. Epub 2009/09/26.

135. Slats D, Claassen J, Lammers GJ, Melis RJ, Verbeek MM, Overeem S. Association between Hypocretin-1 and Amyloid-beta(42) Cerebrospinal Fluid Levels in Alzheimer's Disease and Healthy Controls. Current Alzheimer Research. 2012;9 (10):1119-25. 
136. Roh JH, Jiang H, Finn MB, Stewart FR, Mahan TE, Cirrito JR, et al. Potential role of orexin and sleep modulation in the pathogenesis of Alzheimer's disease. J Exp Med. 2014;211 (13):2487-96. Epub 2014/11/26.

137. Scammell TE, Saper CB. Orexin, drugs and motivated behaviors. Nature Neuroscience. 2005;8 (10):1286-8.

\section{Figure and table legend:}

Table 1: Effects of SB-649868 in adult males with primary insomnia.

The data are from Bettica et al., 2012 [95] and describe: Latency to persistent sleep = LPS, latency to REM $=$ REML, total sleep time $=$ TST, wake after sleep onset $=$ WASO, rapid eye movement sleep $=$ REM, sleep stage $1 \& 2=$ S1 \& S2, slow wave sleep = SWS, as well as the different sleep phases in percentage of total sleep and sleep effciency index $=$ SEI\%, determined using Polysomnography = PSG (standard deviation), in groups treated with placebo or SB-649868 10, 30 or $60 \mathrm{mg}$. Note the absence of effect on SWS, compared to S2 and REM sleep.

Figure 1: Effects of Almorexant in elderly patients suffering from insomnia: The data are from the supplementary information of Roth et al., 2017 [91] and show duration and percentage of, as well as latency to, stage 1 and 2, SWS and REM sleep (95\% confidence intervals) at the increasing doses of 25, 50, 100 and $200 \mathrm{mg}$. Note the main effects on S2 and especially on REM sleep. 


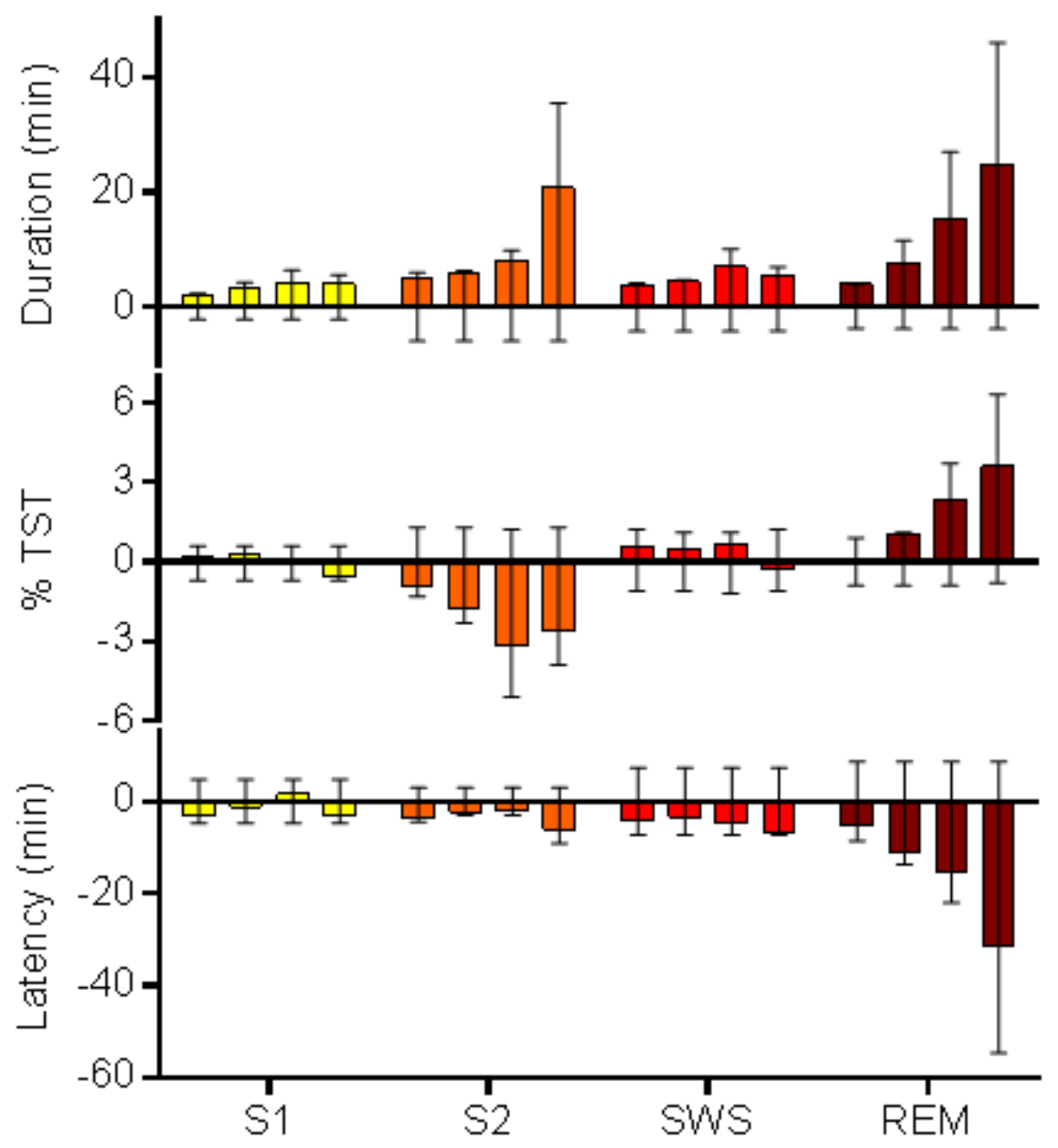


Table 1: Effects of SB-649868 in adult males with primary insomnia.

\begin{tabular}{|c|c|c|c|c|}
\hline PSG Parameter & Placebo & SB-649868 $10 \mathrm{mg}$ & SB-649868 $30 \mathrm{mg}$ & SB-649868 $60 \mathrm{mg}$ \\
\hline LPS (min) & $54.8(38.4)$ & $29.3(22.9)$ & $21.8(21.6)$ & $10.6(10.3)$ \\
\hline REML (min) & $82.8(34.3)$ & $78.3(36.5)$ & $60.9(31.3)$ & $52.4(30.1)$ \\
\hline TST (min) & $367.9(45.7)$ & $390.4(46.8)$ & 417.9 (30.5) & $438.1(19.8)$ \\
\hline WASO (min) & $63.6(33.9)$ & $66.3(42.0)$ & $44.8(26.9)$ & $34.6(18.6)$ \\
\hline REM (min) & $77.6(19.6)$ & $82.5(26.2)$ & $95.7(25.2)$ & $109.6(23.3)$ \\
\hline $\mathrm{S} 1$ (min) & $61.3(21.8)$ & $61.4(21.8)$ & $64.0(21.5)$ & $65.0(22.5)$ \\
\hline $\mathrm{S} 2$ (min) & 201.1 (41.8) & $221.3(35.6)$ & 231.7 (33.2) & $235.2(29.2)$ \\
\hline SWS (min) & $28.0(30.4)$ & $25.1(27.6)$ & $26.5(26.4)$ & $28.3(30.4)$ \\
\hline REM (\%) & $20.8(4.7)$ & $20.8(5.5)$ & $22.8(5.9)$ & $24.9(5.0)$ \\
\hline SEI (\%) & $76.6(9.5)$ & $81.3(9.7)$ & $87.1(6.4)$ & $91.3(4.1)$ \\
\hline S1P (\%) & $17.3(6.5)$ & $16.0(5.8)$ & $15.6(5.9)$ & $15.0(5.7)$ \\
\hline S2P (\%) & $54.2(8.0)$ & 56.9 (7.9) & $55.4(7.6)$ & $53.7(6.7)$ \\
\hline SWSP (\%) & $7.7(8.3)$ & $6.3(6.8)$ & $6.2(6.1)$ & $6.4(6.8)$ \\
\hline
\end{tabular}




\section{University Library}

\section{- M M I E R R V A gateway to Melbourne's research publications}

Minerva Access is the Institutional Repository of The University of Melbourne

Author/s:

Hoyer, D;Jacobson, LH

Title:

Orexin Receptor Antagonists

Date:

2017-12-01

Citation:

Hoyer, D. \& Jacobson, L. H. (2017). Orexin Receptor Antagonists. Current Sleep Medicine Reports, 3 (4), pp.342-353. https://doi.org/10.1007/s40675-017-0099-7.

Persistent Link:

http://hdl.handle.net/11343/282828 